\title{
Using Peer-based Education to Increase the Knowledge Level of Vocational High Students About Sexually Transmitted Diseases
}

\section{Meslek Lisesi Öğrencilerinin Akran Temelli Eğitim ile Cinsel Yolla Bulaşan Hastalıklar Hakkındaki Bilgi Düzeyinin Artırılması}

(D) Gülay Börekçi1,2, (1) Derya Akdeniz Uysal33, (10 Arzu Özel ${ }^{3}$, (1) Döne Aksu³

${ }^{1}$ Mersin University Faculty of Nursing, Department of Nursing Management, Mersin, Turkey

${ }^{2}$ Mersin University Institute of Health Sciences, Department of Molecular Microbiology, Mersin, Turkey

${ }^{3}$ Mersin University Health Research and Application Hospital, Mersin, Turkey

\begin{abstract}
Introduction: Sexually transmitted diseases (STDs) are one of the major health problems affecting especially young people. While the number of newly infected cases with human immunodeficiency virus (HIV), one of the STDs, is decreasing all over the world, unfortunately, it continues to increase in Turkey. Therefore, it is important to educate young people on this topic through effective methodologies. The aim of this semi-experimental study was to evaluate the effectiveness of peer-based education on increasing the knowledge levels of vocational high school students about STDs.
\end{abstract}

Methods: In this study, a peer-based training was provided to 2000 volunteer vocational high school students. Pre- and posttest questionnaire forms prepared by the researchers were filled by the students before and after the training. Of the 2000 volunteer students, the data of 620 students who completed the questionnaire forms were evaluated.

Results: The average age of the participants was $16.58 \pm 1.01$ years and $61.4 \%$ of them were female, of which, $14.5 \%$ were in the $9^{\text {th }}$ grade, $46.0 \%$ in the $10^{\text {th }}, 26.5 \%$ in the $11^{\text {th }}$ and $13.1 \%$ in the $12^{\text {th }}$. Moreover, $67.4 \%$ of them had not received any education on STDs before. A meaningful relationship was found between the results of the pre- and post-tests applied to the students, and the provided training was proven effective in increasing the students' knowledge levels.

Conclusion: The results of this study showed that a peer-based education model can be effective in raising awareness about STDs among youth and in creating a positive behavioural change in them.

Keywords: Sexually transmitted diseases, peer-based education, adolescence

\section{öz}

Amaç: Cinsel yolla bulaşan hastalıklar (CYBH) özellikle gençleri etkileyen önemli sağlık sorunlarından biridir. CYBH'den biri olan insan bağıșıklık yetmezliği virüsü (HIV) ile yeni enfekte sayısı tüm dünyada azalırken, ne yazık ki ülkemizde artmaya devam etmektedir. Bu nedenle gençleri etkili yöntemlerle eğitmek çok önemlidir. Bu yarı deneysel çalıșmanın amacı, akran temelli eğitimin meslek lisesi öğrencilerinin cinsel yolla bulașan hastalıklar konusundaki bilgi düzeylerini artırmadaki etkinliğini değerlendirmektir.

Yöntemler: Bu çalıșmada, gönüllü 2000 meslek lisesi ögrencisine akran temelli eğitim verilmiștir. Araștırmacılar tarafından hazırlanan ön test ve son test soru formu, öğrencilere eğitim öncesi ve sonrasında uygulanmıştır. Veriler toplandıktan sonra, anket formunu dolduran 620 öğrencinin verileri değerlendirmeye alınmıștır.

Bulgular: Araștırmaya katılan öğrencilerin yaş ortalaması 16,58 $\pm 1,01$ olup, $\% 61,4^{\prime}$ ünün kız, \%14,5'inin 9. sınıf, \%46,0'ının 10. sınıf, $\% 26,5^{\prime}$ inin 11. sınıf ve $\% 13,1^{1}$ inin 12 . sınıfta olduğu, $\% 67,4$ 'ünün cinsel yolla bulașan hastalıklar konusunda daha önce hiç eğitim almadığı belirlenmiștir. Öğrencilere uygulanan ön test ve son test arasında anlamlı bir ilișki bulunmuș ve verilen eğitimin öğrencilerin bilgi düzeylerini artırmada etkili olduğu saptanmışıtır.

Sonuç: Çalıșma sonuçlarımız akran temelli eğitim modelinin gençlerin cinsel yolla bulaşan hastalıklar hakkındaki bilgi düzeyinin artırılmasında ve gençlerde olumlu davranış değișikliği olușturulmasında yararlı olduğunu göstermektedir.

Anahtar Kelimeler: Cinsel yolla bulaşan hastalıklar, akran temelli eğitim, adölesan
Address for Correspondence/Yazıșa Adresi: Gülay Börekci PhD, Prof. Dr., Mersin University, Faculty of Nursing, Department of Nursing Management; Institute of Health Science, Department of Molecular Microbiology, Mersin, Turkey Phone: +90 32424100 01/42 23 E-mail: gulay_borekci@yahoo.com ORCID ID: orcid.org/0000-0002-7879-7959

Cite this article as/Atıf: Börekçi G, Akdeniz Uysal D, Özel A, Aksu D. Using Peer-based Education to Increase the Knowledge Level of Vocational High Students About Sexually Transmitted Diseases. İstanbul Med J 2020; 21(4): 266-74.
Received/Gelis Tarihi: 10.07.2019 Accepted/Kabul Tarihi: 09.05.2020

(c) Copyright 2020 by the University of Health Sciences Turkey, Istanbul Training and Research Hospital/Istanbul Medical Journal published by Galenos Publishing House.

(C) Telif Hakkı 2020 Sağıı Bilimleri Üniversitesi Istanbul Ĕgitim ve Araştırma Hastanesi/Istanbul Tıp Dergisi, Galenos Yayınevi tarafından basılmıștır. 


\section{Introduction}

Adolescence is an important transitional period between childhood and adulthood, when the growth and development of a child is swift and the cognitive and psychosocial developments commence $(1,2)$. In Turkey, according to the 2018 Address-based Population Registration System results, out of the total population of $81,867,223$, 12,725,029 people were found to fall within the age group of 10-19 years and 6,402,806 within the 15-19 years (3). Adolescents comprise about one-sixth of the world's total population and about one-fifth of Turkey's. They are an important part of society and are most affected by any social reform or change; however, no special attention on any such accounts is paid to them (4).

The physiological and psychological changes during this transitional period can lead to behavioural changes and cause psychosocial problems among adolescents. Adolescents naturally desire to be independent and seek new environments for themselves, and in doing so, they emotionally distance themselves away from their family. This situation can bring many problems together with new experiences. Some of the common risky behaviours observed among adolescents are substance use, sexually transmitted diseases (STDs), accidents, suicides, violence and adolescent pregnancies (5).

The theme of the World Population Day 2014 was set as "Investing in Young People" by the United Nations Population Fund. And drawing attention to the sexual and reproductive health of adolescents, they stated that very little progress was made in preventing adolescent pregnancies, unsafe abortion, mother deaths, STDs and human immunodeficiency virus/acquired immune deficiency syndrome (HIV/AIDS), and that there are important deficiencies about access to comprehensive sexual education and services and about the quality and availability of this education and these services for the young (6).

STDs are one of the most common and dangerous among infectious diseases. The most frequent STDs are gonorrhoea, syphilis, chlamydia, genital herpes, hepatitis B and HIV/AIDS. According to the WHO data, more than one million people are infected by STDs daily. Each year, 357 million new infections occur with one of the four STDs (chlamydia, gonorrhoea, syphilis and trichomoniasis); besides that, more than 500 million people have genital herpes simplex virus (HSV), and more than 290 million women have human papilloma virus (HPV) infection (7).

According to the United Nations Programme on HIV/AIDS, 36.9 million people were predicted to have HIV/AIDS in 2017; of those, 35.1 million were adults and 1.8 million were children aged under 15. People newly infected with HIV were 1.8 million in 2016, and about 940,000 people died of AIDS and AIDS-related diseases in the same year (8). While newly infected HIV/AIDS cases decrease worldwide, the number continues to rise in Turkey (9).

The insufficiency of sexual education curriculum at schools, unavailability of education to those who do not/cannot go to school, sexuality being regarded as a taboo because of sociocultural reasons, sexuality going down to early age and not knowing about or/and not applying the protection methods are some of the reasons that lead to the risky behaviours observed among adolescents in our country (10). These negligent behaviours pose a risk to their lives in terms of HIV infections and other STDs via unprotected sex or intravenous drug use. This is why educating the youth at high school age about the types of STDs and the precautions to take and using a peer-based education to do so are important. Peer education-based on social learning theoryis established on the fact that young people interact with their peers and identify with each other (11). The classical education is generally teacher-centred, where knowledge is one-way process from the educator to the student. On the other hand, in the peer education, children use similar language and influence each other creating a more positive and interactive learning environment (12). Therefore, in our study, we aimed to determine the effect of peer-based education on the knowledge levels of students about STDs.

Although, in recent years, much awareness on the topic has been created through social media, sexuality and related topics are still regarded as taboo and are not given place in education, yielding the awareness attempts on the topic so far as inadequate. Since STDs affect the age group of 15-24 the most, educating young people is especially important. However, the fact that young people do not have sufficient information about STDs at that age, that they do not obtain information from right sources and that they are misinformed cause difficulties in fighting against these diseases. It was identified through different studies in our country that students have insufficient information about STDs, and that they do not want to get information about STDs (13-17).

Mersin is a cosmopolitan tourist city with high migration rate and has been exposed to sociocultural changes since a long time. In our country, vocational high school students settle in schools with the lowest grades and their education includes mostly vocational knowledge. These students, who have more free time, are at risk for substance use and STDs. The results of our former study on this group showed that students do not have sufficient information about STDs.

\section{Methods}

This study was conducted semi-experimentally using the pre- and posttest forms in order to determine the effect of peer-based education on students' level of knowledge about STDs. A total of 20,961 students studying between the $9^{\text {th }}$ and the $12^{\text {th }}$ grade of 22 vocational high schools were included in this study. The sample consisted of 2,000 students selected from these vocational high schools through random sampling method. Before starting to work, ethical approval was obtained from the Clinical Research Ethics Committee of Mersin University and the other necessary permissions (governorship approval, ministry of education permission slip) were taken from related institutions.

In the first stage of the study, all 2,000 students were asked to fill a questionnaire in order to determine their level of knowledge about STDs. After that, the structure of the peer-based education, including the modes of transmission, their symptoms and prevention, was planned. Then, the educational materials (power point presentation, brochure, etc) were prepared.

In the second stage, approximately 50 university students were trained by specialists about STDs. These university students (peers) were mostly nursing department students at a university or students of other faculties who had taken lessons on STDs before. 
In the third stage, a peer-based training about STDs was given to the 2,000 participating high school students by the 50 university students under the leadership of 16 researchers. Peer-based trainings on STDs were delivered in a 45 mins-long single session to groups of 20-50 students in the conference halls of the schools. Data were collected using the pre- and post-test forms prepared by the researchers. Students were asked to fill the pre-test form before and post-test form after the session. In addition, at the end of the session, students were given leaflets with information about STDs. Descriptive characteristics information form and STDs information form, prepared by the researchers in line with the literature, were used for data collection. The demographic information form included questions about the students' age, gender, school, department, and class. The STDs information form included questions about STDs, the modes of transmission of the diseases, symptoms and consequences, treatment and prevention. There were 51 questions in the survey together with their subgroups.

Finally, after the data were collected, the data of only 620 students who completed the questionnaire forms were evaluated. The data obtained were analysed using a statistics package program in computer environment. Percentage, arithmetic mean, standard deviation values, and chi-square test were used for data analysis. The results were evaluated as between 95\% confidence interval and $p<0.05$ was considered as significant.

\section{Results}

The average age of the students was $16.58 \pm 1.01$ years and $61.5 \%$ of them were female, of which $14.5 \%$ were in the $9^{\text {th }}$ grade, $46.0 \%$ in the $10^{\text {th }}, 26.6 \%$ in the $11^{\text {th }}$ and $12.9 \%$ in the $12^{\text {th }}$. Department wise, $20.6 \%$ of the students were in child development, $20.2 \%$ in accounting, $9.2 \%$ in graphics, $8.1 \%$ in electrics-electronics and less in other departments; $67.4 \%$ of the students stated that they had not received any education about STDs.

When the pre- and post-test results of the knowledge of the students about STDs was compared, it was found that there was a statistically significant difference between before and after the education, and that the knowledge level about STDs increased after the education. The increase in the number of students who were aware of HIV/AIDS, hepatitis $B$, hepatitis $C$, syphilis, trichomoniasis and others as forms of STDs after the education was found to be statistically significant $(p<0.05)$. Likewise, the number of students who knew about the different modes of transmission of STDs before and after the training increased significantly $(p<0.05)$ (Table 1$)$.

\section{Table 1. Comparison of the pre- and post-test results of the knowledge of the students regarding the different modes of transmissions of} STDs

\begin{tabular}{|l|l|}
\hline Pre-test & Post-test \\
\hline $\mathrm{n} \%$ & $\mathrm{n} \%$ \\
\hline
\end{tabular}

p

\section{Transmission through sexual intercourse}

No

Do not know

\begin{tabular}{|l|l|}
\hline 533 & 86.1 \\
\hline 11 & 1.8 \\
\hline 75 & 12.1 \\
\hline
\end{tabular}

Transmission through cheek kissing

Yes

No

Do not know

148

295

175

Transmission through respiration

Yes

No

Do not know

\begin{tabular}{|l|l|}
\hline 263 & 42.7 \\
\hline 170 & 27.6 \\
\hline 183 & 29.7 \\
\hline
\end{tabular}

Transmission through some commonly used tools (injector, razor, manicure set, etc)

Yes

No

Do not know

395

72

151

Transmission from mother to baby during pregnancy and breastfeeding

Yes 299

No

Do not know

99

116

204

Transmission through blood and organ transfusion (HIV/AIDS, hepatitis B/C)

Yes

No

Do not know

Total

285

60

304

620

\begin{tabular}{|l|l|}
\hline 578 & 93.8 \\
\hline 12 & 1.9 \\
\hline 26 & 4.2 \\
\hline
\end{tabular}

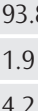

4.2

37.0

54.1

8.9

\begin{tabular}{|l|l|}
\hline 295 & 47 \\
\hline 249 & 40 \\
\hline 76 & 12.3 \\
\hline
\end{tabular}

47.7

40.0

12.3

$471 \quad 76.2$

\begin{tabular}{l|l}
79 & 12.8
\end{tabular}

\begin{tabular}{l|l}
68 & 11.0
\end{tabular}

0.001

24.4

2.8

\begin{tabular}{|l|l|}
\hline 469 & 75.8 \\
\hline 76 & 12.3 \\
\hline 74 & 12.0 \\
\hline
\end{tabular}

\section{8}

12.3

12.0

0.001

33.0

47

76.3

14.4

49.0

100
9.4

14.4

100
0.001 p: chi-square test was used, HIV/AIDS: human immunodeficiency virus/acquired immune deficiency syndrome, STDs: sexually transmitted diseases 
When the knowledge levels of students regarding the symptoms and results of STDs before and after the training were compared, it was found that their knowledge levels increased significantly after the training $(p<0.05)$ (Table 2).

When the knowledge levels of students regarding the treatment of STDs before and after the training were compared, it was found that their knowledge levels increased significantly after the training $(p<0.05)$ (Table 3).

As shown in Table 4, when the knowledge levels of the students related to the precautions to be taken to protect themselves against STDs before and after the training were compared, it was found that the increase in the knowledge levels after the test was statistically significant $(p<0.05)$.

Table 5 shows the knowledge levels of students about vaccination against STDs before and after the training, and it was found that the increase in the knowledge levels after the training was statistically significant $(p<0.05)$.

\section{Discussion}

The biggest risk that unsafe sexual life can bring is an STD. Protection is the most essential step in prevention of STDs. However, this can only be achieved if the younger population is educated on the issue and has a positive outlook towards using protection. While there are many methods of imparting education, peer-based education can be particularly effective in societies where STD is considered as a taboo. In our study, the effect of peer-based education on the knowledge levels of vocational high school students about STD was researched.

Students' knowledge on the different types of STDs increased significantly after the peer-based training. While trichomoniasis (16.5\%) and Chlamydia infections (18.7\%) and gonorrhoea (27.9\%) were among the least known STDs before the training, a significant rise was seen in these rates after the training. Similarly, in a study of nursing school first grade students by Așcl et al. (17), it was found that the rate of defining STDs among the risks sexual life can bring increased significantly among the participants after a peer-based training. While the rate of students viewing STDs as a risk was $67.2 \%$ before the education, it increased to 87.9\% after the education. In the same study, the rate of those who knew the names of STDs other than HPV, HSV, Chlamydia and Trichomonas infections increased after the training. Furthermore, in a study by Jones et al. (18) with university students including nursing school students in the United States, an increase in the knowledge level of students about STDs was determined after a peer-based training. Also, in several other studies with university and high school students, a significant difference was found in the knowledge levels of students about STDs before and after peer-based education (19-22).

After the literature review, it was found that the studies conducted in many different countries concentrated mostly on HIV/AIDS, and that peer-based education interventions were done (23-29). A Malaysian research among medical and health school students studied the effect of peer-based education on the knowledge, attitude and risky health

Table 2. Comparison of the pre- and post-test results of the knowledge of students about the symptoms and results of STDs

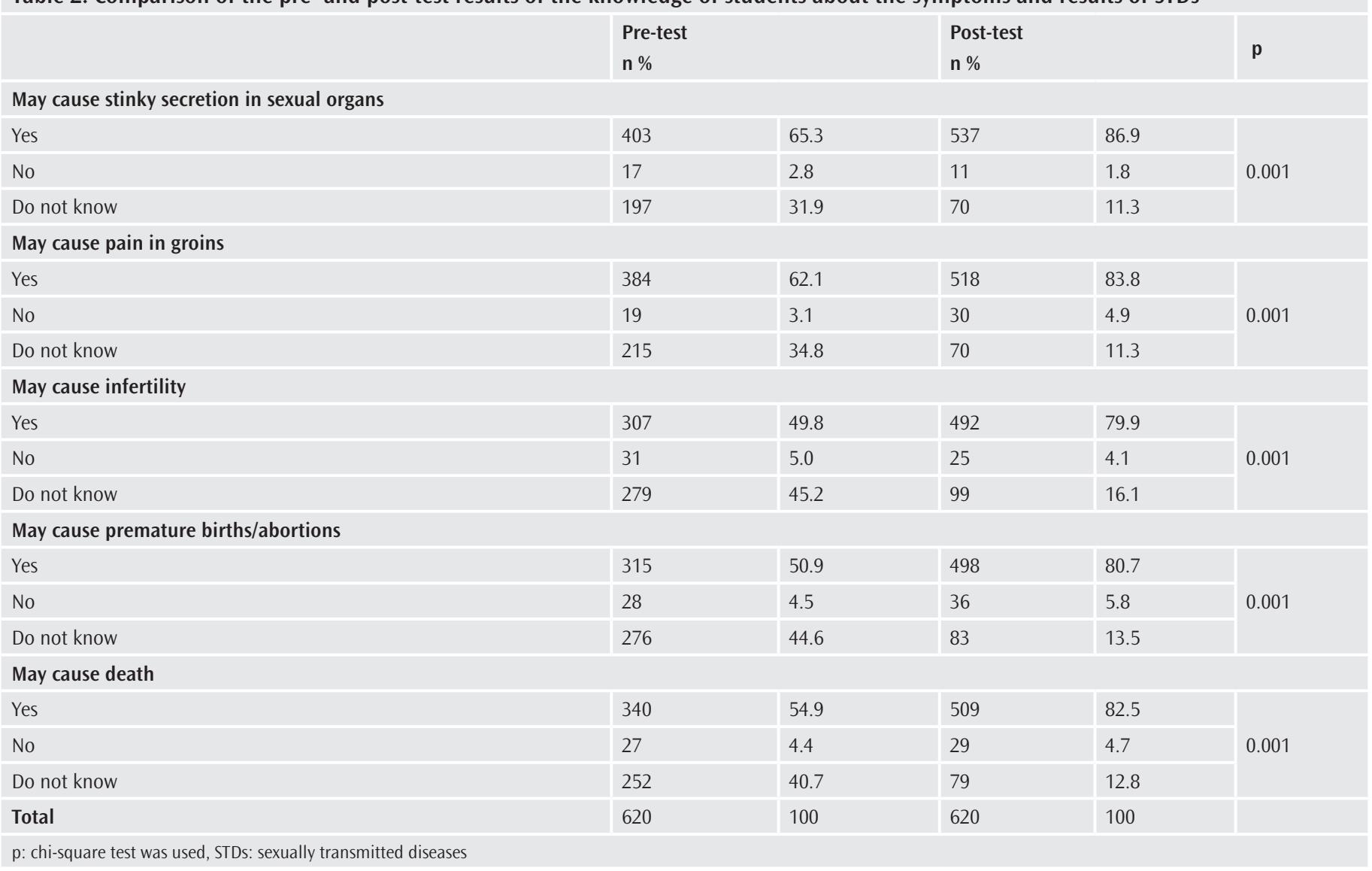


Table 3. Comparison of the pre- and post-test results of the knowledge of students about the treatment of STDs

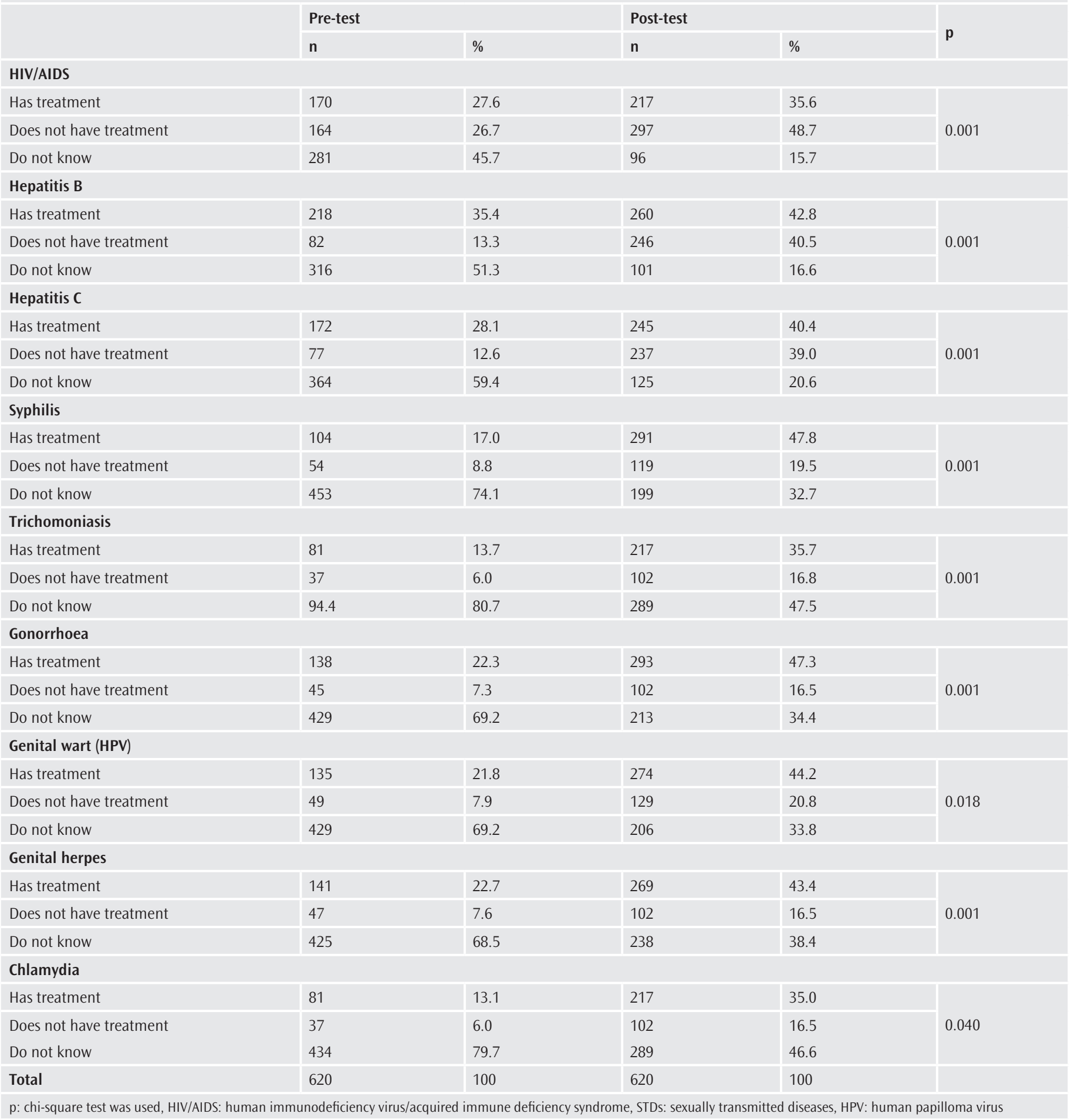

behaviours related to HIV, and it was found that the knowledge level of the group who received the education increased significantly compared to the control group (26). In the study of Jahanfar et al. (24), an increase in the knowledge level of the group that was given peer-based education about HIV/AIDS was found. In similar studies in Iran, after the peerbased education was given to adolescents, knowledge and attitude points of the group receiving the training on HIV/AIDS were found to increase significantly compared to the control group $(27,28,30)$. In randomly controlled studies of Bulduk and Erdogan (31) and Calloway et al. (23), a significant increase in the HIV/AIDS knowledge levels of the group that received the training was detected.

In our study, when the knowledge levels of the students related to the modes of transmissions of STDs before and after the peer-based training was compared, the knowledge levels of students was found 
Table 4. Comparison of the pre- and post-test results of the knowledge of students about the precautions to be taken against transmitted STDS

\begin{tabular}{|c|c|c|c|c|c|}
\hline & \multicolumn{2}{|c|}{ Pre-test } & \multicolumn{2}{|c|}{ Post-test } & \multirow{2}{*}{ p } \\
\hline & n & $\%$ & $\mathbf{n}$ & $\%$ & \\
\hline \multicolumn{5}{|c|}{ Maintaining monogamy in sexual intercourse } & \multirow{3}{*}{0.00} \\
\hline No & 48 & 7.7 & 37 & 6.0 & \\
\hline Do not know & 271 & 43.7 & 90 & 14.6 & \\
\hline Yes & 225 & 36.3 & 473 & 77.0 & \multirow{3}{*}{0.001} \\
\hline No & 65 & 10.5 & 36 & 5.9 & \\
\hline Do not know & 329 & 53.2 & 105 & 17.1 & \\
\hline \multicolumn{5}{|c|}{ Avoiding intercourse with risky people (sex workers, homosexuals) } & 0.001 \\
\hline \multicolumn{5}{|c|}{ Avoiding common use of tools like razor, injector, nail clipper } & \multirow{4}{*}{0.001} \\
\hline Yes & 386 & 62.7 & 487 & 79.4 & \\
\hline No & 38 & 6.1 & 46 & 7.5 & \\
\hline Do not know & 195 & 31.5 & 80 & 13.1 & \\
\hline Total & 620 & 100 & 620 & 100 & \\
\hline
\end{tabular}

to increase after the training $(p<0.05)$. This finding matches to similar studies conducted by using peer-based education $(17,22)$. The results obtained from our study also matches with similar studies conducted by using peer-based education $(15,18)$. In Așçı et al. (17) study, the number of students knowing modes of STD transmission other than vaginal intercourse increased significantly when compared with before the education. In the study of Ali et al. (29) in Sudan, the rate of the correct answer given to the question of modes of transmission of HIV increased after the peer-based education from $75.5 \%$ to $83.2 \%$.

When the knowledge levels of students related to the symptoms and results of STDs in our study were examined, it was seen that the knowledge levels of students related to the symptoms and results of STDs increased after receiving the training. Similarly, in the study of Aşcı et al. (17), the number of students knowing the symptoms of STDs was found to increase significantly after the education compared to before the education, and the difference was found to be statistically significant.

In our study, the knowledge levels of students related to the precautions that should be taken to be protected from STDs increased significantly after the education. In the study of Kırmızıtoprak and Şimşek (22) with young people, the answers given about safe sexual intercourse as avoiding sexual intercourse, monogamy and condom usage in protection from STDs changed positively after the peer-based education. While $77 \%-79.9 \%$ of students did not know the precautions stated before the education, the rate of students who did not know decreased to
4.7\%-6.1\% after the education. In the same study, the rate of students who knew condom as the most reliable method increased significantly after the education from $31 \%$ to $60.3 \%$. In a study by Miller et al. (25) in Kenya with university students, a significant decrease in the number of students stating that condom use is not safe in protection from HIV was detected after a peer-based education. In another study, the rate of correct answers given by students with respect to having more than one sexual partner would increase HIV/AIDS risk increased from $47.5 \%$ to $83.5 \%$ after receiving the peer-based education (29). In the study of Adeomi et al. (32), while the rate of the correct answers about the ways of protection from AIDS showed an increase in the group who was given education, the same result was not seen in the control group.

In our study, the knowledge levels of students about vaccination and treatment of STDs increased after receiving the education. In comparison of the before and after the education, a statistically meaningful difference was observed. Similar to our study, in the study of Adeomi et al. (32), the knowledge level of students about the treatment of AIDS increased compared to the control group after the education.

However, like every study, there are some limitations to this study. The study was conducted only in vocational high schools in Mersin and included students who were present in the school on the day of training and volunteered to participate in the research. Due to the large number of students and the problem of time, all students could not be reached to check the pre- and post-test forms. 
Table 5. Comparison of the pre- and post-test results of the knowledge of students about the vaccination against STDs

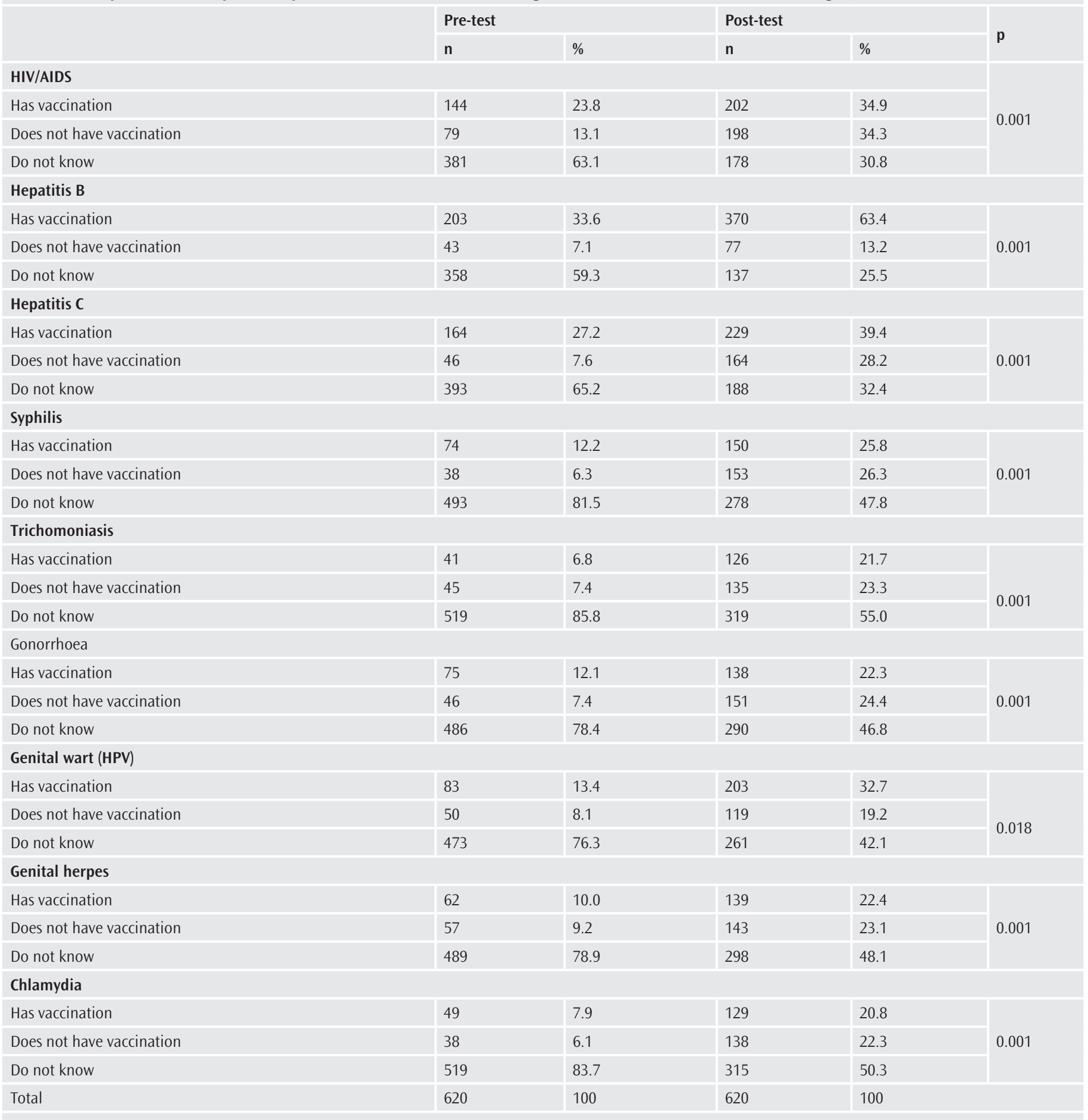

p: chi-square test was used, HIV/AIDS: human immunodeficiency virus/acquired immune deficiency syndrome, HPV: human papilloma virus, STDs: sexually transmitted diseases

\section{Conclusion}

In our study, the increase in the knowledge levels of knowing the names of STDs, their symptoms and results, vaccination and treatment after the education shows that the young people do not have sufficient information related to STDs, and that the peer-based education is efficient. Especially among adolescents, who are generally under the influence of their peers in many ways including in terms of positive and negative health behaviours. Young people tend to obtain and share information about sexual health-one of the taboo topics in our society from and among individuals who are in a similar developmental stage as them (22). This is why peer-based education, where they can have comfortable sharing without being judged that can enable their knowledge levels about STDs, is an educational approach that has 
been frequently used in recent times (19). We believe that peer-based education model would be beneficial in educating young people about STDs and in creating positive behavioural changes in them. It would be useful to implement and spread peer-based training in schools to prevent HIV/AIDS and STDs.

\section{Acknowledgement}

We would like to thank all the students and teachers in Vocational High School in Mersin, Turkey.

\section{Ethics}

Ethics Committee Approval: Ethical approval was obtained from the Clinical Research Ethics Committee of Mersin University and the other necessary permissions (governorship approval, ministry of education permission slip) were taken from related institutions (decision no: 78017789/050.01.04/348, date: 09.10.2015).

Informed Consent: In addition, permission was obtained from students before the questionnaires were applied.

Peer-review: Externally peer-reviewed.

Authorship Contributions: Concept- G.B., D.A.U., A.Ö., D.A.; Design - G.B.; Data Collection or Processing - D.A.U., A.Ö., D.A.; Analysis or Interpretation - G.B., D.A.U., A.Ö., D.A.; Literature Search - D.A.U., A.Ö., D.A ; Writing - G.B., D.A.U., A.Ö.

Conflict of Interest: No conflict of interest was declared by the authors.

Financial Disclosure: The authors declared that this study received no financial support.

\section{References}

1. Yiğit R. Growth and development in childhood. 1st ed. Ankara: Ofset Printing; 2012.

2. Güler Y, Gönener DH, Altay B, Gönener A. Obesity and nursing care in adolescents. Firat Health Services Journal 2009; 4: 165-81.

3. TUIK. Turkey Statistical Institute Address Based Population Registration System Results in 2016. Available from: URL: http://www.tuik.gov.tr

4. Yılmaz A, Başkan S. Evaluation of primary and high school students' knowledge about AIDS. The Journal of Current Pediatrics 2014; 1: 9-15.

5. Karatay G, Kubilay G. The Determination of substance use and influenced factors at two high school; which have different socio-economic status. Journal of Research and Development in Nursing 2004; 1: 57-70.

6. UNFPA: United Nations Population Fund (2014). World population day investment in youth. Available from: URL: http://www.un.org.tr/news/ WPD2014BilgiNotu.pdf

7. WHO: World Health Organisation (2019). Sexually transmitted infections (STIS). Available from: URL: https://www.who.int/en/news-room/fact-sheets/detail/ sexually-transmitted-infections-(stis)

8. UNAIDS: Global HIV\&AIDS statistics-2018 fact sheet. Available from: URL: https://www.unaids.org/en/resources/fact-sheet.

9. T.C. Ministry of Health, General Directorate of Public Health, Department of Infectious Diseases. HIV-AIDS Statistics. Available from: URL: https:// hsgm.saglik.gov.tr/tr/bulasici-hastaliklar/862-hiv-aids/1135-h\%C4\%B1v-aidsistatislik.html
10. Efetürk T, Karabacak O. Sexual health at adolescence: Risky sexual behaviour. Turkiye Klinikleri J Fam Med-Special Topics 2013; 4: 71-80.

11. Akkuş D, Eker F, Karaca A, Kapısız Ö, Açıkgöz F. High school youth peer education program an effective model to prevent substance abuse happen? Journal of Psychiatric Nursing 2016; 7: 34-44.

12. Ünver V, Akbayrak N. Peer tutoring model in nursing education. DEUHYO ED 2013; 6: 214-7.

13. Karaköse A, Aydın S. Examination of young men's knowledge about sexually transmitted diseases. New Journal of Urology 2011; 6: 33-9.

14. Beydağ KD. A group of university school for health sciences students HIV/AIDS knowledge level. TAF Preventive Medicine Bulletin 2007; 6: 59-68.

15. Özdemir L, Ayvaz A, Poyraz Ö. The level of knowledge of students in Cumhuriyet University about the sexually transmitted diseases. Journal of the Faculty of Medicine Cumhuriyet University 2003; 25: 10-4.

16. Özalp S, Tanir HM, Ilgin H, Ilgin B. Evalution of knowledge and atttitude of Eskişehir Osmangazi University Medical and Agricultural Faculty's students on sexually transmitted diseases and family planning. Duzce Medical Journal 2012; 14: 18-21.

17. Așcı Ö, Gökdemir F, Çiçekoğlu E. Efficiency of training on reproductive health provided by peer trainers to nursing students. HSP 2016; 3: 173-83.

18. Jones SG, Patsdaughter CA, Jorda ML, Hamilton M, Malow R. SENORITAS: An HIV/sexually transmitted infection prevention project for Latina college students at a Hispanic-serving university. JANAC 2008; 19: 311-9.

19. Güçlü $S$, Elem E, Unutkan A. An Intervention to increase sexual health information levels of youth: Peer education project. Journal of Research in Education and Teaching 2015; 4: 56-162.

20. Dağ H, Dönmez S, Şirin A, Kavlak O. University youth reproductive and sexual health knowledge and peer education. Journal of Anatolia Nursing and Health Sciences 2012; 15: 10-7.

21. Kadıoğlu H, Yıldız A. Effects of sexual education with the peer-led and adult led on the knowledge and attitudes of the elementary school eight grade students about the sexuality. HEMAR-G 2007; 3: 28-44.

22. Kırmızıtoprak E, şimşek Z. The effect of peer-education on sexually transmitted diseases and safer sexual life knowledge and behaviour of young people. TAF Preventive Medicine Bulletin 2011; 10: 463-72.

23. Calloway DS, Long-White DN, Corbin DE. Reducing the risk of HIV/AIDS in African American college students: An exploratory investigation of the efficacy of a peer educator approach. Health Promotion Practice 2014; 15: 181-8.

24. Jahanfar S, Lye M, Rampal L. A randomised controlled trial of peer-adultled intervention on improvement of knowledge, attitudes and behaviour of university students regarding HIV/AIDS in Malaysia. Singapore Medical Journal 2009; 50: 173-80.

25. Miller AN, Mutungi M, Facchini E, Barasa B, Ondieki W, Warria C. An outcome assessment of an ABC-based HIV peer education intervention among Kenyan university students. J Health Commun 2008; 13: 345-56.

26. İbrahim N, Rampal L, Jamil Z, Zain AM. Effectiveness of peer-led education on knowledge, attitude and risk behaviour practices related to HIV among students at a Malaysian public university- A randomized controlled trial. Prev Med 2012; 55: 505-20.

27. Abbaspour Z, Saidian M, Abedi P. Peer education vs health provider education in knowledge and attitude about prevention and transmission of AIDS in high school students. Pak J Med Sci 2007; 23: 108-10. 
28. Babazadeh T, Zibaei N, Shabani L, Moradi F. Effectiveness of educational intervention based on peer education on knowledge, attitude and behavioral intention related to HIV/AIDS in the high school female students in the region 14 of Tehran. JECH 2015; 2: 19-27.

29. Ali MHM, Osman OB, Ibrahim MAM. The effect of AIDS peer health education on knowledge, attitudes, and practices of secondary school students in Khartoum, Sudan. AIMS Public Health 2015; 2: 718-26.

30. Alizadeh Siouki H, Jadgal K, Shamaeian Razavi N, Zareban I, Heshmati H, Saghi N. Effects of health education based on health belief model on nutrition behaviors of primary school students in Torbat e Heydariyeh city in 2012. Journal of Health 2015; 5: 289-99.

31. Bulduk S, Erdogan S. The effects of peer education on reduction of the HIV/sexually transmitted infection risk behaviors among Turkish university students. JANAC 2012; 23: 233-43.

32. Adeomi AA, Adeoye OA, Asekun-Olarinmoye EO, Abodunrin OL, OlugbengaBello A, Sabageh AO. Evaluation of the effectiveness of peer education in improving HIV knowledge, attitude, and sexual behaviours among in-school adolescents in Osun State, Nigeria. AIDS Research and Treatment 2014; 1-10. 